Research article

\title{
Studies on the reproductive biology of Wiesnerella denudata (Mitt.) Steph. - a rare hepatic
}

\begin{abstract}
Anu Sharma* and Madhu Bhagat
Department of Botany, University of Jammu, Jammu-180006, Jummu \& Kashmir, India

*Corresponding Author: anu4botany@gmail.com

[Accepted: 22 October 2017]

Abstract: Wiesnerella denudata is a rare monotypic thalloid hepatic of the family Wiesnerellaceae (Order: Marchantiales). During the course of present investigation, ten districts of Jammu region in Jammu\& Kashmir were explored, but the only single population was collected from Dhera Ki Gali, Poonch. As it is a rare hepatic, the present communication deals with its reproductive biology. It was interesting to note that the species does not undergo propagation by any vegetative means. Further, the thalli with only female receptacles were recorded. However, well-developed sporogonium differentiated into the foot, seta and capsule were observed along with a very high spore-elater ratio. The status of the species in the Jammu region of Jammu and Kashmir (NorthWest Himalayas) with special emphasis on its unique reproductive biology and the consequences of its dependence on only a single mode of propagation (sexual) have been discussed.
\end{abstract}

Keywords: Hepatic - Monotypic - Rare - Spore-elater ratio - Mycorrhiza.

[Cite as: Sharma A \& Bhagat M (2017) Studies on the reproductive biology of Wiesnerella denudata (Mitt.) Steph. - a rare hepatic. Tropical Plant Research 4(3): 396-400]

\section{INTRODUCTION}

Wiesnerella denudata (Wiesnerellaceae; Marchantiales) is distributed in Eastern and Western Himalayas, Indonesia, China, Korea, Hawaii and Borneo (Chang \& Wu 2006, Ludwiczuk \& Asakawa 2010). In India, it has been reported from Jammu \& Kashmir (Tanwir \& Langer 2007), Himachal Pradesh (Kaur et al. 2010), Nagaland (Eshuo 2012), Sikkim (Singh et al. 2008), West Bengal (Hattori 1966) and Uttarakhand (Kanwal 1977). From Nainital, it was recorded from Dhobighat, growing on the black muddy stream associated with several other liverworts (Conocephalum conicum (L.) Dum., Dumortiera hirsuta (Sw.) Nees, Marchantia paleacea Bertol. and Pellia endivaefolia (Dicks.) Dum. (Kanwal 1977). However, it could not be collected from Dhobighat nor anywhere else in Nainital (Pant 1983). According to her, indiscriminate and ruthless collection of this liverwort resulted in its disappearance and she listed it in the threatened category along with other nine hepatic taxa [Conocephalum conicum (L.) Dum., Dumortiera hirsuta (Sw.) Nees, Reboulia hemispherica (L.) Raddi, Sewardiella tuberifera Kashyap, Wiesnerella denudata (Mitt.) Stephani, Cryptomitrium himalayensis Kash., Fossombronia himalayensis Kashyap, Athalamia pinguis Falc. and Stephensoniella brevipedunculata Kash.]. Other workers like Udar \& Srivastava (1983), Pant et al. (1994) and Srivastava (1998) enlisted it in the rare category in Kumaon and Eastern-Western Himalaya.

Several studies have been conducted on the chemical constituents of Wiesnerella denudata (Asakawa et al. 1980, Kumar et al. 2007, Kaur et al. 2010, Huang et al. 2012) but studies on its other aspects have received less attention. During the present investigation, a single population of the genus was collected from Poonch district at an elevation of $2350 \mathrm{~m}$ inhabiting rock surface. Ecological data collected for this accession has been tabulated in table 1. Present paper deals with the morphology, anatomy and reproductive biology of Wiesnerella denudata thus collected.

\section{MATERIAL AND METHODS}

Frequent visits were made in different districts (Doda, Jammu, Kishtwar, Kathua, Poonch, Rajouri, Ramban, Reasi, Samba, Udhampur) of Jammu division ranging in altitude from 305-2350 m. Only one accession inhabiting rock surface was collected from Dherakigali (Poonch). In order to record various stages of the life 
cycle, periodic visits were made at the site of collection of Wiesnerella denudata in Poonch district. Data on the date of collection, altitude, temperature and relative humidity of the place of the collection was recorded. Observations on habitat, morphology, number of receptacles/thallus, their shape, size and position of antheridia, archegonia, sporophytes/receptacle per thallus and number of spores and elaters/capsule were made. Spore elater ratio per capsule was determined by applying the formula:

Total number of spores per capsule / Total number of elaters per capsule.

Repeated the same procedure for five capsules and took out the mean value.

\section{RESULTS AND DISCUSSION}

\section{Phenology}

In the month of August with frequent showers, thalli started rejuvenating from the dried patches. The thalli remained in vegetative phase until the end of September. In the second week of October, sessile and small female receptacles started appearing. Archegonia with long necks developed between mid-November and the end of December. Male receptacles could not be collected due to heavy snowfall in the site of the collection during January to March. Fertilization might have occurred during mid-December to January and sporophytes started developing by the end of January. The mature sporophytes containing spores and elaters were seen in the first week of April. Temperature range has been tabulated in table 1.

Table 1. Details of asexual and sexual reproduction.

\begin{tabular}{|c|c|c|c|c|c|c|c|c|c|c|}
\hline \multirow{2}{*}{$\begin{array}{l}\text { Site of } \\
\text { collection }\end{array}$} & \multirow{2}{*}{$\begin{array}{l}\text { Altitude } \\
\text { (m) }\end{array}$} & \multirow{2}{*}{ pH } & \multirow{2}{*}{$\begin{array}{l}\text { Date of } \\
\text { collection }\end{array}$} & \multirow{2}{*}{$\begin{array}{l}\text { Temperature } \\
\left({ }^{\circ} \mathrm{C}\right)\end{array}$} & \multirow{2}{*}{$\begin{array}{l}\text { Humidity } \\
(\%)\end{array}$} & \multirow{2}{*}{$\begin{array}{l}\text { Asexual } \\
\text { reproduction }\end{array}$} & \multirow{2}{*}{$\begin{array}{l}\text { Male } \\
\text { Receptacle }\end{array}$} & \multicolumn{3}{|c|}{ Archegonia } \\
\hline & & & & & & & & $\bar{Y}$ & $\mathbf{M}$ & $\mathrm{CD}$ \\
\hline Dherakigali & 2350 & 7.5 & 15.10 .2012 & $20-29$ & $46-68$ & Not observed & Not & + & - & - \\
\hline (DKG) & & & 25.12 .2012 & $4.7-16$ & $39-53$ & & & + & - & - \\
\hline (Epilithic) & & & 05.04 .2013 & $25-29$ & $78-90$ & & & - & + & + \\
\hline & & & 23.02.2014 & $5.8-7.2$ & $78-94$ & & & + & - & - \\
\hline
\end{tabular}

Note: $\mathbf{Y}=$ young; $\mathbf{M}=$ mature; $\mathbf{C D}$ = capsules dehisced; + = Present; - = Absent.

\section{Morphology}

Thalli of $W$. denudata are dichotomously branched, $2.0-3.5 \mathrm{~cm}$ long and 1-2 cm broad, nearly flat above, margin wavy, lobes oblong to quadrate, notched at the apex and occur in large extended yellowish green or light green patches of irregularly overlapping individuals as shown in figure 1A. Dorsal surface with distinct areolae; ventral surface green with inconspicuous scales along the midrib region (Fig. 1B); air pores large, slightly convex bounded by 2-3 rings of cells with 5-8 cells per ring, spherical to elliptical in surface view (Fig. 1C); Scales in two rows, lunate with a single filiform appendage. Rhizoids of two types, smooth walled and tuberculated, the former being more in frequency as shown in figure $1 \mathrm{D}$.

\section{Anatomy}

Thallus differentiated into dorsal narrow photosynthetic and ventral wider storage zone. The air pore lacks the papillae. Photosynthetic zone comprises of unistratose air chambers, chlorophyllous; air chambers small, distant, filled with rudimentary filaments (Fig. 1E).

\section{Reproduction}

It reproduces only by sexual means. So far, no vegetative/asexual means of reproduction have been reported nor seen in the population under study (Table 1).

Plant monoecious or dioecious; Tanwir (2005), reported male plants from the area and described their position on the mid-dorsal groove of the thallus, behind the stalk of female receptacle or at notch, sessile to subsessile, cushion-like surrounded by short, hyaline papillose scales; female receptacle in the present study were 1-3 (1.8 \pm 0.45$)$ per thallus, terminal arising from deep narrow notchat the apex, stalked; stalk 3-11 $(6.9 \pm 1.79) \mathrm{mm}$ with two rhizoidal furrows, receptacle convex, 4-6 (5.1 \pm 0.50$)$ lobed; diameter of disc 2-5 $(3.8 \pm 0.53) \mathrm{mm}$, involucres under the lobe (Fig. 2A; Table 1). Female receptacles had long necks before fertilization (Fig. 2B) and after fertilization neck started degenerating and venter broadened. Sporogonium differentiated into the foot, seta and capsule (Fig. 2C). The diameter of the capsule was 1510.6-1643.4 $\mu \mathrm{m}$ (1565.38 \pm 29.29$)$. Spores having diameter 36.56-49.80 $\mu \mathrm{m}(34.69 \pm 3.73)$ were yellowish brown to dark brown, reticulate, winged; wings broad, lobed, wavy (Fig. 2D); elaters yellowish brown, narrow, and bispiralled (Fig. 2E); 265.6-398.4 $\mu \mathrm{m}(335.32 \pm 22.94)$ long and 4-8 $\mu \mathrm{m}$ (7.28 \pm 0.77$)$. Spore and elater output were 1302-3435

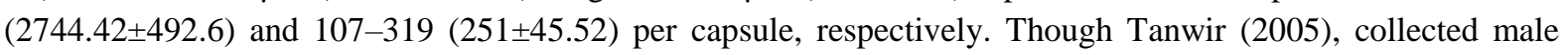


receptacles from this area, during the present study, it was not possible due to heavy snowfall in the area from January to March.
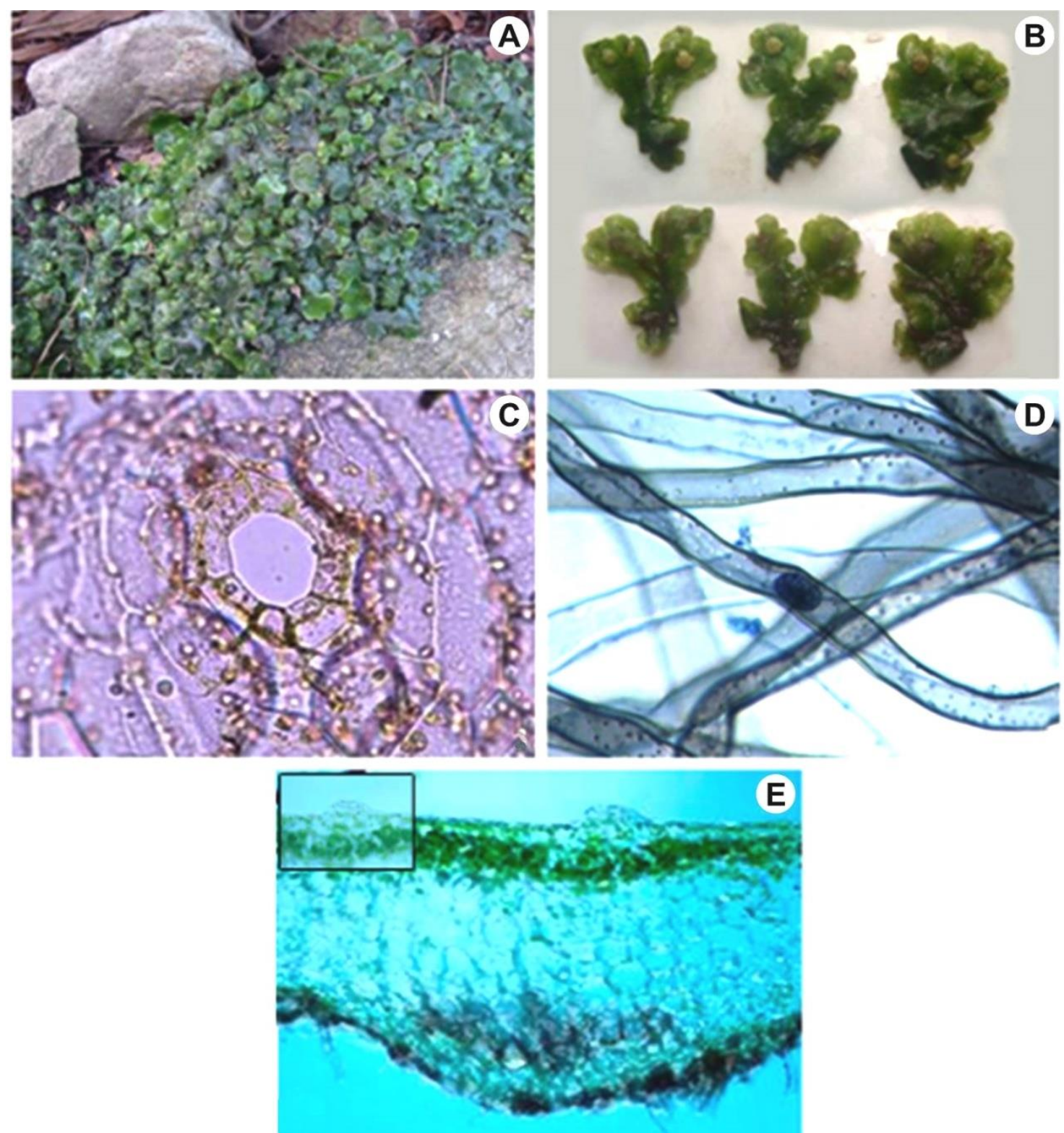

Figures 1. A, Patch of Wiesnerella denudata growing on epilithic habitat; B, Thalli in dorsal and ventral view; C, Whole mount of epidermal peeling showing air pore; $\mathbf{D}$, Whole mount of smooth walled and tuberculated rhizoids showing hyphal strands and a vesicle; E, V.S. of thallus showing upper photosynthetic and lower storage zone (Inset- Notice raised air pore).

Huang et al. (2012) and Chang \& Wu (2006) have reported the genus to be dioecious. According to Lindberg (2000), a higher proportion of dioecious species as compared to monoecious ones fail to produce sporophytes. Low spore output may be a possible cause of rarity for dioecious hepatics but in the present case, no rarity has been observed in spore production. Moreover, the spore elater ratio has been recorded to be higher compared to the normal ratio found in Marchantialean members (4:1) (Schuster 1996). Thus, high spore output indicates its successful sexual reproduction and survival rate. Furthermore, a smaller number or absence of asexual propagules coincides with having a large number of spores (Soderstorm \& During 2000). In present work also, the authors observed the absence of any asexual structures. It means that asexual reproduction has no role to play in the propagation of the species. But what about its rare nature? It is a serious question to ponder about. Since the population is producing sporophytes, it is obvious that sexual reproduction is taking place successfully. Though the authors were not able to collect male plants because of high snowfall in the area from January to March, it is quite obvious that both the sexes were present in the population. The serious situation is that if the plant is not producing any vegetative structures for propagation, what would happen if in near future 
the habitat destruction ruins the limited population. According to Miles \& Longton (1990), spores act as a more efficient means of long-distance dispersal than vegetative propagation. In the present case, the populations are not distributed to the wide range; it means that spore dispersal is occurring within a narrow patch. This may lead to less genetic diversity/low variability within the population.

Thus the possible causes of its rarity in Jammu \& Kashmir may be:

(1) lack of vegetative reproduction,

(2) low dispersal range of spores and thus low genetic variability,

(3) low spore viability in spite of high spore output.
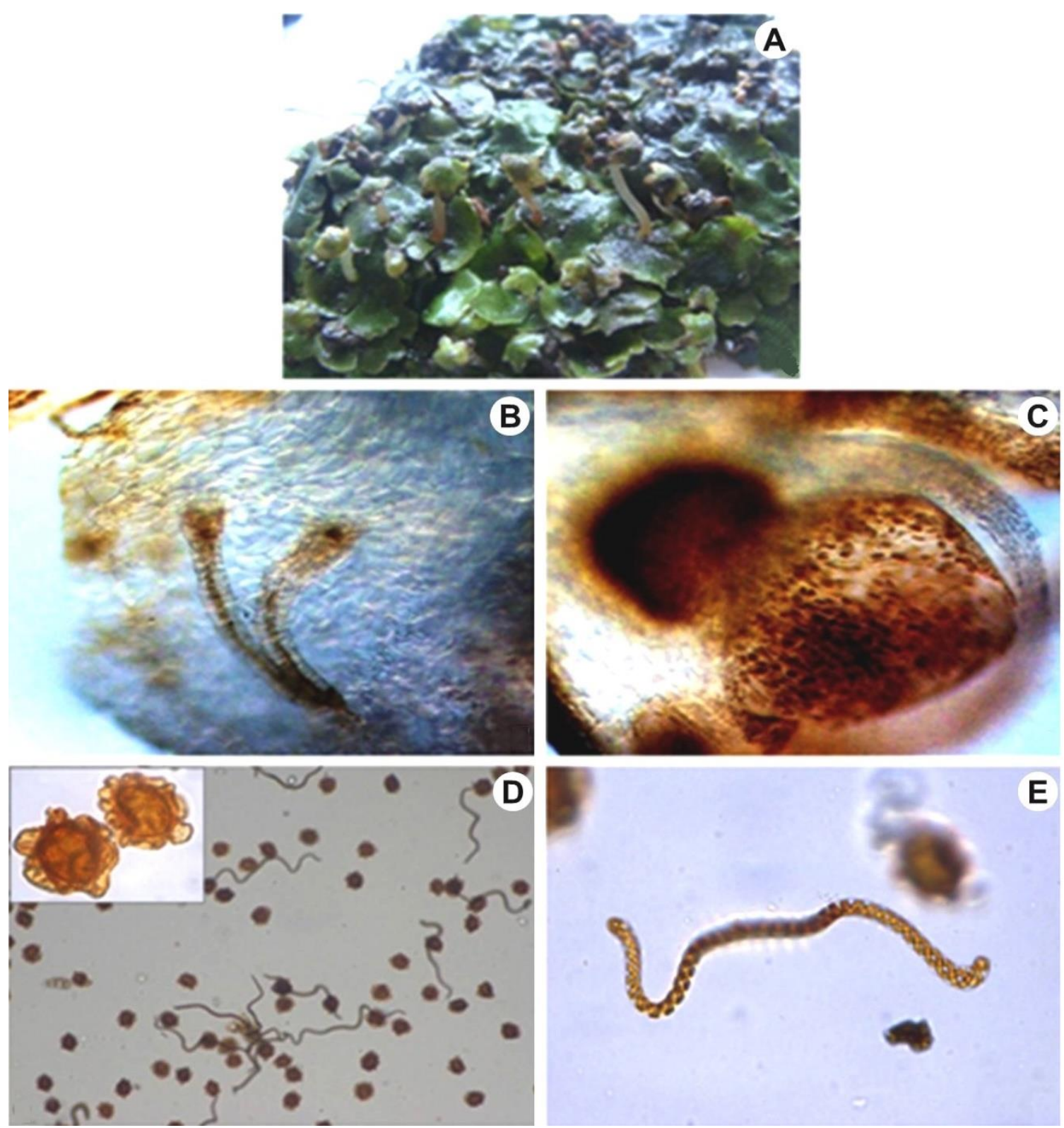

Figures 2. A, Fully mature female receptacles on the thallus; B, V.S. of female receptacle passing through archegonia bearing long necks; C, V.S. of female receptacle showing post fertilization stage with mature sporophyte bearing foot, seta and capsule; D, Whole mount of spores and elaters (Inset- Spores at high magnification); E, Whole mount of elater showing long and bispiralled bands.

\section{CONCLUSION}

The genus is rare, and if in near future the restricted populations are not able to withstand the adverse environmental threats, the species may most likely fall into the category of threatened hepatics. So, the final conclusion may be drawn only after studying more and more populations with an emphasis on its genetic structure along with their spore viability. Further studies and comparison of spore elater ratios of different populations are needed to arrive at any definite conclusion. 


\section{ACKNOWLEDGEMENTS}

The authors wish to thank the Head, Dept. of Botany, University of Jammu, for providing the necessary laboratory facilities. Special thanks to Dr. S. K. Singh (Scientist C, BSI, Eastern Regional Centre) for identifying the plants and to Meteorology Department, $\mathrm{J} \& \mathrm{~K}$ for providing the temperature and relative humidity data. The authors declare that they have no conflict of interest.

\section{REFERENCES}

Asakawa Y, Matsuda R \& Takemoto T (1980) Mono and sesquiterpenoids from Wiesnerella denudata. Phytochemistry 19: 567-569.

Chang YL \& Wu PC (2006) Spore Morphology of Chinese Bryophytes. Quingdao Publishing House, Quingdao.

Eshuo K (2012) Diversity of thalloid liverworts and their conservation in Nagaland, India. In: International conference of biodiversity and sustainable energy development. Journal of Ecosystem and Ecology 2(4): 124.

Hattori S (1966) Anthocerotae and Hepaticae. In: Hara H (ed) The flora of eastern Himalaya. University of Tokyo Press, Tokyo, pp. 501-536.

Huang SF, Chang CH, Liu CC \& Chiu YP (2012) Notes on the Wiesnerella denudata (Mitt.) Steph. (Wiesnerellaceae, Hepaticae) in Taiwan. Taiwania 57: 318-321.

Kanwal HS (1977) Marchantiales of district Nainital (Kumaon Hills) UP, India. Reviews of Bryology and Lichenology 31(3): 327-328.

Kaur S, Rao A \& Kumar SS (2010) Study on some of the contents of some bryophytes-I Anthocerotae and Hepaticae. International Journal of Pharmaceutical sciences review and research 5(2): 018.

Kumar K (2007) Concept of bryophytes in classical text of India in ethnobotanical perspective. In: Nath V \& Asthana AK (eds) Current Trends in Bryology. Bishen Pal Singh and Mahendra Pal Singh, Dehradun, India, pp. 169-170.

Lindberg SL (2000) Substrate preference and reproduction in Lophozia silvicola (Hepaticopsida) in Southern Finland. Annales Botanici Fennici 37: 85-93.

Ludwiczuk \& Asakawa Y (2010) Chemosystematics of selected liverworts collected in Borneo. Tropical Bryology 31: 33-42.

Miles CL \& Longton RE (1990) The role of spores in reproduction in mosses. Botanical Journal of the Linnean Society 104: 149-173.

Pant GB (1983) Threatened bryophytes of Nainital. In: Jain SK \& Rao RR (eds) Assessment of threatened plants of India. Botanical Survey of India, Dept. of environment, Botanical garden, Howrah, pp. 313-317.

Pant GB, Tewari SD \& Joshi S (1994) Vanishing greenery in Kumaon Himalaya: Observations on Bryoflora. Geophytology 23: 253-257.

Schuster RM (1996) The Hepaticae and Anthocerotae of North America. Colombia University Press, New York.

Singh DK, Singh D \& Dey M (2008) A Catalogue of the Hepaticae and Anthocerotae of Sikkim. In: Mohamed H, Baki BB, Nasrulhaq-Boyce A \& Lee PKY (eds) Bryology in the New Millennium. University of Malaya, Kuala Lumpur, pp. 93-135.

Soderstorm L \& During HJ (2000) Bryophyte rarity viewed from the perspective of life strategy and metapopulation dynamics. Journal of Bryology. 27: 261-268.

Srivastava SC (1998) Distribution of hepaticae and anthocerotae in India. In: Chopra RN (ed) Topics of Bryology. Allied Publishers, New Delhi, pp. 53-58.

Tanwir M \& Langer A (2007) Distributional pattern of hepatics of tehsil Mendhar (North-West Himalaya) with special emphasis on Rare and Endemic taxa. In: Nath V \& Asthana AK (eds) Current trends in Bryology. Bishen Pal Singh and Mahendra Pal Singh. Dehradun, India. pp. 353-364.

Tanwir M (2005) Studies on the diversity of hepatic flora of district Poonch (North-West Himalaya). M. Phil. Dissertation. University of Jammu, Jammu, India.

Udar R \& Srivastava SC (1983) Rare and endangered liverworts in India. In: Jain SK \& Rao RR (eds) An assessment of threatened plants of India. Botanical Survey of India, Howrah, pp. 303-312. 